Lucjan Kocik

Uniwersytet Papieski

Jana Pawła II w Krakowie
Kiedy myślimy Rodzina..., red. M. Duda, K. Kutek-Sładek, Kraków 2016, s. 25-33 (Praca Socjalna w Teorii i Działaniu, 2).

\title{
Rodzina współczesna w kręgu opresyjnych wzorów społeczeństwa liberalnego
}

\author{
Modern family in circle oppressive patterns \\ liberal society
}

\begin{abstract}
Postmodernism and globalization results has changed contemporary meanings of marriage and family. This situation is based on the level of "political correctness" and strikes against the strong values of religion and contemporary family system. This cause
\end{abstract}

many disharmonious situation in different branches of family functions.

Keywords: postmodernism, globalization, social values, political correctness, marriage, family

Ogólnospołeczne zmiany, które współcześnie zaczynają dominować, nazywane też „ponowoczesnością” i globalizacją, są tak wszechstronne, że obecnie nawet dotychczasowe definicje rodziny i małżeństwa przestają być adekwatne do istniejącej rzeczywistości. Rodzina przestaje być instytucją, grupą i systemem o trwałych, zunifikowanych i uniwersalnych cechach. Pojawiają się najróżnorodniejsze alternatywne formy życia małżeńsko-rodzinnego. Formy te są sankcjonowane przez narastającą tendencję do indywidualizacji wzorów życia, która ściśle związana jest z neutralizacją aksjonormatywną i etyczną globalizującego się świata.

Na gruncie tej etycznej neutralizacji rodzą się określone formy nowych „dyktatur", w pewnym sensie sprzeczne same w sobie oraz zagrażające poczuciu własnej (osobowościowej) tożsamości, której miały służyć i którą miały utwierdzić. 
Są to między innymi: dyktatura tolerancji, dyktatura wyzwolonego pożądania oraz dyktatura autonomicznych, indywidualnych wyborów. Zjawiska te wywołują niezwykle poważne reperkusje we wszystkich wymiarach dotychczasowej pozycji rodziny oraz sposobów jej funkcjonowania w społeczeństwie. Wiążą się one we względnie spójną całość w taki sposób, że jedna forma dyktatury wynika z drugiej. Natomiast wspólną ich cechą jest to, że unikają, a nawet starają się neutralizować i zupełnie eliminować tzw. „twarde” i trwałe wartości, wokół których mogą być tworzone projekty życiowe ${ }^{1}$.

Pojawienie się bardzo modnej obecnie w zachodnim świecie zasady poprawności politycznej, która przekształciła się w dyktaturę tolerancji, nastąpiło w kręgu ideologii skrajnie liberalnej. Odrzuca ona możliwość jakichkolwiek wartościujących porównań między kulturami, a co więcej deklaruje, że wszystkie mają taką samą wartość. Niedopuszczalna jest więc krytyka lokalnych obyczajów, zwyczajów, stylu życia, wierzeń czy praktyk. Równie niedopuszczalna jest apologia jakiejkolwiek kultury. Terminy sugerujące, że coś jest niższe lub wyższe, gorsze lub lepsze, zacofane lub postępowe, prymitywne lub rozwinięte, barbarzyńskie lub cywilizowane, nie mają prawa bytu w słowniku zwolenników tzw. politycznej poprawności i zastąpione zostały jednym terminem: „inny”. Co więcej, nie tylko ocena, ale i prezentacja jakiejkolwiek kultury musi zapewnić jej traktowanie na równi z pozostałymi.

Nurt, z którego wyłoniła się zasada poprawności politycznej, wyrasta z realnej problematyki i broni na ogół słusznych spraw. Należą do nich: podrzędna pozycja kobiet we wszystkich społeczeństwach, znacznie trudniejsza przeszłość i trudniejsza obecna sytuacja ludzi o innym niż biały kolorze skóry, liczne przejawy braku tolerancji w świecie, jednostronny kanon zachodniej kultury itp.

Atrakcyjność poprawności politycznej bierze się stąd, że ogólne postulaty wydają się jak najbardziej słuszne każdemu względnie rozsądnemu i wrażliwemu człowiekowi, który bierze na serio czy to chrześcijańskie przesłanie miłości bliźniego, czy to rewolucyjne przesłanie wolności, równości i braterstwa, czy to inne pobożne życzenia.

Walka o nowe programy nauczania na wydziałach humanistycznych amerykańskich uniwersytetów stała się bodaj główną areną, na której zamanifestowały się skrajne formy poprawności politycznej. W gruncie rzeczy nie była to nawet walka o nowe programy, lecz o zniszczenie dotychczasowego curriculum, które istotnie było i jest jawnie seksistowskie i rasistowskie, a także anachroniczne.

Charakterystyczną cechą omawianego sposobu myślenia jest bodaj przekonanie, iż wszystkie różnice między ludźmi sprowadzają się ostatecznie do inno-

1 Zob. szerzej: L. Kocik, Rodzina w obliczu wartości i wzorów ponowoczesnego świata, Kraków 2006, s. 135n. 
ści, inność zaś jako taka jest ze swej natury godna szacunku. Nie ma przeto na tej ziemi rzeczy pięknych i brzydkich, lecz są co najwyżej rzeczy piękne inaczej; nie ma rzeczy mądrych i głupich, lecz są co najwyżej rzeczy mądre inaczej; nie ma sensu i bezsensu, są tylko sensy rozmaite. Każda rzekoma niższość jest w istocie innością, którą powinniśmy wartościować pozytywnie, nie ulegając presji panującej ideologii, zgodnie z którą wszystko, co inne, jest tym samym gorsze. Nie ma kultury i braku kultury, są tylko różne kultury, których nie mamy prawa ustawiać w porządku hierarchicznym, gdyż oznacza to opowiadanie się kulturą dominującą czy hegemoniczną.

Otóż, wydawałoby się, że nie mając nic przeciwko wielokulturowości, można mniemać, iż coś jest lepsze, a coś gorsze. Nieprawda, wszystko jest bowiem równie dobre, z wyjątkiem kultury panującej, czyli znienawidzonej kultury dyskryminacji. Być innym, aniżeli ona nakazuje, to cnota największa; żadne inne wartości się nie liczą.

Polityczna poprawność stała się przekleństwem kultury i polityki przełomu XX i XXI wieku. Często oznaczała konieczność poddania się politycznie poprawnemu odprawieniu rytuału nad kłamstwami i opresją w historii i wypływających z nich postulatów moralnego zadośćuczynienia jako warunku legitymowanego funkcjonowania w społeczeństwie. Każdy system wartości musi być uznany za absolutnie równy w kulturze. Państwo liberalno-demokratyczne ma zatem dążyć do instytucjonalizacji relatywizmu, wykluczając w sferze publicznej jakiekolwiek próby rozróżniania między dobrem a złem, między wartościami wzmacniającymi i niszczącymi kulturę, a wraz z nią sferę publiczną. Samo takie rozróżnienie zostało zdelegitymizowane jako z założenia represjonujące. Filozofia zakładająca, iż każdy jest nosicielem swojej własnej, subiektywnej i nieprzekraczalnej prawdy, stała się aksjomatem liberalnego myślenia. Wraz z takim myśleniem została zdelegitymizowana jakakolwiek próba głoszenia w sferze publicznej wartości „mocnych”, uznanych za totalitarne i rodzaj gwałtu moralnego mogący przerodzić się w gwałt polityczny.

Tak zrodziła się doktryna światopoglądowej neutralności państwa. Doktryna $\mathrm{z}$ jednej strony wewnętrznie sprzeczna, $\mathrm{z}$ drugiej niebezpieczna, gdyż pociąga za sobą konieczność karania tych, którzy wartości „mocne” wyznają, i uznawania ich za potencjalnie niebezpiecznych w sferze publicznej. Rodzi ona zatem pokusę tropienia nosicieli tych wartości i eliminacji ich postaw instytucjonalnych. Oznacza to, iż państwo odczuwa pokusę uderzenia w te instytucje, w których rodzą się czy mogą się rodzić - owe wartości „mocne”, np. w Kościoły, a także w rodzinę².

2 Za: A. Bryk, Akcja afirmatywna, doktryna różnorodności a plemienna koncepcja społeczeństwa liberalnego, [w:] „Krakowskie Studia Międzynarodowe”, red. A. Bryk, t. 1, nr 2 (2004), s. 48n. 
Jeśli idzie o moralność, np. seksualną, rezultatem powinna być albo zupełna dobrowolność, albo kompletna obojętność. Nikt nie powinien wtrącać się w to, co robisz ze swoim ciałem, i nikt nie powinien mieć nawet poglądu na temat tego, co robisz ze swoją duszą. Fałszywe czy przestarzałe mieszanie duszy z ciałem jest okrutnym pozbawieniem ciała przyjemności cielesnej.

W logice takiego ideologicznego rozumowania mieści się też przymusowa liberalna edukacja seksualna w szkołach od najmłodszych lat, dystrybucja w nich prezerwatyw, jednostronna edukacja dotycząca w tym kontekście AIDS, traktowanie wszystkich „stylów” seksualności jako legitymizowanego wyboru, a więc nie jedynie ich tolerowanie, ale akceptowanie jako równouprawnionych w kulturze; stąd postulat konieczności ich nauczania na tych samych warunkach w programach edukacyjnych. Powyższe działania są traktowane jako odblokowanie przez regulację ze strony państwa i prawa represyjnej seksualności, jej „wyzwolenie” z represyjnego wychowania rodzin czy religii. Do tego typu działalności należy ruch na rzecz tzw. „małżeństw” homoseksualnych, ruch mieszczący się w logice wolnego wyboru nieograniczonej jednostkowej jaźni, swojego „stylu życia” i następnie żądania jego zaakceptowania w strukturze prawa państwowego.

Dla ułatwienia akceptacji nowej formy „wyzwolenia” dokonuje się w ramach systemu politycznej poprawności neutralizacji tych pojęć i terminów, które tradycyjnie wiązały się ściśle z określonymi wartościami społecznymi i moralnymi.

W ponowoczesnym języku przestępca to „ofiara społeczeństwa”, wierność małżeńska to „represyjna seksualność”, kaleka to „sprawny inaczej”, głupi to „mądry inaczej”, dewiant to „kochający inaczej” lub osoba „o odmiennej orientacji seksualnej”, przerwanie ciąży to „przywrócenie (wywołanie) menstruacji”, małżonek to „partner seksualny”, sadyzm, masochizm, zoofilia czy nekrofilia to „niekonwencjonalne upodobania” lub „seks ekstremalny” itp. itd. Są to przykłady tego, jak bardzo relatywizuje się rzeczywistość, jak odbiera się właściwe znaczenie określonym cechom ludzkim lub sytuacjom społecznym, jak bardzo unika się nazywania rzeczy po imieniu po to, aby uniknąć wartościowania, a unikać wartościowania, by nie spoglądać prawdzie w oczy.

Sam brak różnorodności stawał się kryterium niesprawiedliwego działania instytucji publicznych. Co więcej, i taka była prawdziwie dramatyczna konsekwencja doktryny różnorodności, jej brak stawał się w hałaśliwej propagandzie różnorako zdefiniowanych grup mniejszościowych kryterium oceny prawomocności działania publicznego instytucji prywatnych o całkowicie dobrowolnym członkostwie. Doktryna różnorodności rozprzestrzeniła się po całym amerykańskim społeczeństwie, przenikając jego instytucje i kulturę. Staje się też stopniowo częścią języka i prawa publicznego świata zachodniej demokracji liberalnej, np. w Unii Europejskiej. 
Grupy takie, jak np. homoseksualiści, transwestyci, prostytutki, pedofile, sekty religijne różnego autoramentu, narkomani czy kryminaliści, od lat 70. XX wieku nie godziły się na akceptację dominującego, większościowego kodu kulturowego, i w konsekwencji prawnego, który wykluczałby ich ze społeczeństwa. Uznawały jedynie woluntarystycznie pojmowaną koncepcję moralności, bowiem każda inna „obowiązująca i narzucona”, a nie „wybrana”, jest moralnością represyjną. W takiej sytuacji jednak następuje radykalna zmiana pojęcia dewiacji czy marginesu, które stają się pojęciami anachronicznymi i bezsensownymi. Zastępuje je rozstrzygająca kategoria swobodnego, autonomicznego podmiotu.

Według takiego rozumowania heteroseksualizm i małżeństwo kobiety z mężczyzną nie mogą być preferowaną organizacją życia ludzkiego, konieczną dla przedłużenia bytu społecznego, najlepszą, sprawdzoną doświadczeniem ludzkim formą organizacji dla wychowania dzieci. Stają się formą uzurpacji kulturowej oraz uzurpacji władz i z definicji mają być zdelegalizowane jako wymagające szczególnej ochrony społecznej - twierdzą aktywiści tożsamości gejowskiej. Jeśli zatem mają być zdelegalizowane jako wyjątkowe w kulturze, to znaczy, że tę wyjątkowość należy społecznie, ekonomicznie, politycznie zniszczyć i należy w tym celu użyć instrumentów prawnego przymusu administrowanego przez państwo.

Stąd też płynie uzasadnienie tzw. „małżeństw homoseksualnych” czystą miłością. Dlaczego, pytają homoseksualiści, nie możemy być „małżonkami”, przecież się kochamy tak jak heteroseksualiści. Jest to analogia zbudowana na już zredukowanej, zbastardyzowanej instytucji małżeństwa jako warunku koniecznego do legitymizacji jej odpowiednika. Instytucja ta ma się opierać jedynie na miłości. Jeśli tak, to stan emocjonalny miłości ma tę samą wartość, niezależnie od płci osób, które są nią złączone. Problem w tym, iż tylko poprzez strywializowanie i zniszczenie tradycyjnego wyobrażenia małżeństwa w kulturze Zachodu można roszczenie homoseksualistów próbować uzasadnić. W tym sensie bezprecedensowy atak na małżeństwo trwający w kontrkulturze od lat 60. - z oderwaniem seksu od miłości, dzieci od odpowiedzialności rodzicielskiej, z instytucją rozwodów „bez winy” etc. - przygotował grunt pod atak homoseksualny, będący ostatnim etapem na drodze do zniszczenia instytucji, która nie ma już żadnego wsparcia ani w kulturze, ani w instytucjach prawnych. Instytucji, która choć nie jest żadnym modelem uniwersalnym, jest jedną z najcenniejszych zdobyczy kulturowych - obok chrześcijańskiego pojęcia „osoby” chronionej tabu Boga, rządów prawa czy praw człowieka - cywilizacji Zachodu. Wraz ze zniszczeniem małżeństwa, tak jak i stopniowym niszczeniem pojęcia jednostkowej i niezniszczalnej „osoby” chronionej tabu Boga w związku z „wypłukiwaniem” i spychaniem na margines chrześcijaństwa, cywilizacja Zachodu w ta- 
kim kształcie, w jakim istniała przez ostatnie 2 tysiące lat, odchodzi do historii, a wraz z nią odchodzi autonomia i wolność jednostki.

Tolerancja jest nakazem umożliwiającym znośne współżycie ludziom posiadającym mocne, ale różne przekonania. Rozciągnięcie tej zasady na zakaz posiadania jakichkolwiek mocnych przekonań w sferze publicznej nie jest realizacją idei liberalnych, tylko gwałtem popełnionym na liberalizmie. Zamiast wolności przekonań proponuje wolność od przekonań. Ale do czego może być człowiekowi potrzebna wolność, skoro nie wolno posiadać własnych przekonań.

Dzisiejsza socjologia uznaje, że społeczeństwo znajduje się w nieustannym procesie zmian. W każdym momencie historycznym pojawia się przed nim pewne pole możliwości. Co stanie się w przyszłości, zależy od tego, co ludzie uczynią dzisiaj - poprzez działania indywidualne, zbiorowe, ruchy społeczne, reformy polityczne, rewolucje. Zakłada się przy tym, że ludzie tworzący historię otrzymują pole manewru od swoich poprzedników. Naszymi dzisiejszymi działaniami tworzymy z kolei nowe terytoria wyboru dla nas samych w przyszłości i dla naszych następców. Przyjmuje się także, że historia nie jest $\mathrm{z}$ góry zdeterminowana, lecz zawiera wachlarz możliwych scenariuszy, a więc że przyszłość jest otwarta. I wreszcie, że występuje tu znaczny stopień indeterminacji, przypadkowości i niepewności. W toku zmian społecznych zdarzają się rzeczy nieprzewidziane.

Często przy podejmowaniu zbiorowych decyzji wielka rolę odgrywają nieprzewidywalne imponderabilia: nastroje, emocje, niekiedy dalekie od zimnej nieracjonalności, na przykład znudzenie, oburzenie, uniesienie się honorem, poczucie godności, obrona tożsamości. Implikacją takiej wizji jest postawa aktywistyczna: „Pozwalaj sobie na marzenia i działaj tak, aby twoje marzenia się spełniły”. Nie wystarczy przewidywać, trzeba działać dla przyszłości, konstruować ją.

Jeżeli z takiej perspektywy zadamy pytanie o wyzwania XXI stulecia, to odpowiedź na nie sprowadzi się do rozpoznania pola możliwości działania, jakie istnieje we współczesnym świecie, a w którego obrębie otwierają się różne scenariusze dla jego przyszłych losów. Pole to ma pewną fundamentalną właściwość. Jest nią ambiwalencja, niejednoznaczność występujących tendencji i stojących za nimi wartości, a często ich wzajemna przeciwstawność. Dlatego można mówić o dylematach. Efektem są napięcia, antagonizmy, konflikty, a realizacja takiego a nie innego scenariusza przyszłości zależy od tego, jakie siły społeczne w starciu tych tendencji wygrywają.

Oto główne dylematy przyszłości³:

3 Podaję w skrócie za: P. Sztompka, Szok przyszłości. Dziesięć dylematów XX wieku, „Wprost” z 5.01.2003. 
1) Indywidualizm czy wspólnota? Z jednej strony, mamy afirmację jednostki, akcent położony na jej dobro, indywidualną odpowiedzialność za jej czyny, konkurencję, gotowość do ryzyka. Z drugiej strony, odczuwamy potrzebę zakorzenienia we wspólnocie, myślenia o sobie i innych za pomocą zaimka „my”, poczucia więzi społecznej.

2) Globalizacja czy tożsamość lokalna? Z jednej strony, mamy uniformizację kultury, wiedzy, sztuki, stylu życia, napędzaną rozwojem technologii komunikacyjnych, telekomunikacyjnych, komputerowych. Z drugiej jednak strony dążenie do obrony i zachowania odrębności lokalnych, własnych, swoistych sposobów życia, idei i ideałów.

3) Interesy czy wartości? Z jednej strony, mamy instrumentalne i racjonalne, oparte na kalkulacji i wyrachowaniu dążenie do realizacji własnych, egoistycznych interesów i narcystycznych pragnień. Z drugiej strony, mamy świat wyższych i stałych wartości, których realizacja może wymagać uwzględnienia dobra innych, a zatem wyrzeczeń, rezygnacji, odłożenia na później własnych korzyści.

4) Społeczeństwo masowe czy jakość życia? Z jednej strony, mamy demokratyczny imperatyw, aby wszelkie pożądane przez ludzi dobra, takie jak: masowa edukacja, masowa kultura, masowa turystyka, masowa motoryzacja itp., były coraz powszechniej dostępne. Z drugiej strony, chcielibyśmy uchronić jakość tych dóbr - osobisty kontakt wykładowcy ze studentem, puste plaże nadmorskie, przejezdne szosy i łatwe do znalezienia parkingi. A to może zapewnić tylko pewien stopień elitaryzmu i ograniczonego dostępu do takich dóbr.

5) Kult nowości czy afirmacja tradycji? Z jednej strony, cieszy nas nowość: nowe doświadczenie, rewolucja obyczajowa, nowe gadżety, nowe style w modzie, nowe tony w muzyce. $Z$ drugiej strony, pragniemy kontynuacji, odnajdujemy ontologiczne bezpieczeństwo w trwałych zwyczajach, obyczajach, sposobach życia, w niezmiennym otoczeniu tych samych przedmiotów czy urządzeń.

6) Dorywcze zajęcia czy życiowa kariera? Z jednej strony, coraz częściej traktujemy pracę jako krótkoterminowe, incydentalne zajęcie, które może wymagać zmiany, przekwalifikowania się, szybkiej adaptacji do nowych warunków. Z drugiej strony, tęsknimy za całościowym projektem życiowym, długoterminową karierą, stałością zatrudnienia, lojalnością ze strony firmy, w której pracujemy.

7) Konsumpcja czy samorealizacja? Z jednej strony, fascynuje nas świat produktów, urządzeń, używek, rozrywek. Chcemy jak najwięcej zawłaszczyć, jak najwięcej mieć. Z drugiej strony, jesteśmy wiecznie niezaspokojeni w pogoni za uciekającą mnogością coraz to nowych pokus i czujemy potrzebę czegoś więcejsamorealizacji w twórczości, wierze religijnej, refleksji intelektualnej, harmonii rodzinnej. Chcemy, jak powiada Erich Fromm, nie tylko „mieć”, ale też „być”.

8) Kontraktowa intymność czy trwała rodzina? Z jednej strony, zachłystujemy się swobodą seksualną, luźnymi związkami intymnymi opartymi tylko na 
wzajemnej przyjemności „aż do odwołania”, nieograniczoną wolnością doboru partnerów, rozdzieleniem seksu i uczucia. Z drugiej strony, brakuje nam zakorzenienia i oparcia w trwałej, pewnej, ustabilizowanej rodzinie łączącej wzajemnie odpowiedzialnych, lojalnych i cieszących się zaufaniem jej członków. Brakuje nam romantycznych uniesień i chodzenia z głową w obłokach.

9) Demokracja w rękach wybranych czy dyskurs publiczny? Z jednej strony, chętnie oddajemy nie tylko decyzje, ale i odpowiedzialność wybieranym od czasu do czasu reprezentantom i z satysfakcją zrzucamy na elity polityczne winę za wszelkie trudności. Z drugiej strony, pragnęlibyśmy mieć stały wpływ na wszelkie ważne dla nas sprawy, chcielibyśmy, aby nasz głos był donośny i słyszany, aby nasze zdanie się liczyło.

10) Informacja czy mądrość? $Z$ jednej strony, toniemy w nieograniczonym bogactwie coraz łatwiej dostępnych informacji, faktów, danych empirycznych, statystyk. Z drugiej strony, szukamy mądrości, a więc wizji, sensu, mapy, idei ogólnej, teorii wyjaśniającej.

Ekspansja nowoczesnej formacji, a zwłaszcza jej skrajna artykulacja w fazie tzw. późnej czy wysokiej nowoczesności, prowadzi do dominacji takich akcentów: jak indywidualizm, globalizacja, interesowność, masowość, kult nowości, dorywczość pracy, konsumpcjonizm, kontraktowa intymność, idea demokracji elitarnej i fetysz informacji. Dominacja tego syndromu to nie jest jednak wcale fatalistyczna konieczność.

Na przeszkodzie do całkowitego, jednostronnego zwycięstwa takiego sposobu życia społecznego staje czynnik, który socjologowie określają jako społeczną refleksyjność. Chodzi o to, że ludzie dysponują możliwością świadomej refleksji nad swoją sytuacją i kierunkiem, w jakim zmierza świat. Najpierw refleksji czysto intelektualnej, zarówno systematycznej, filozoficznej, naukowej, jak i bardziej spontanicznej, potocznej, a następnie - organizowania się i mobilizowania do działań zaradczych, przeciwstawiających się dominującym tendencjom poprzez ruchy społeczne, religijne, organizacje pozarządowe, partie, akcje parlamentarne czy politykę rządową. I w ten sposób może się dokonywać zwrot w stronę drugich - wypartych czy zapomnianych - biegunów każdego z wymienionych dylematów, przywrócenie życia społecznego.

Przyszłość to niekoniecznie to, co już było, tylko jeszcze więcej, a więc społeczeństwo jeszcze bardziej nowoczesne, nieznośnie nowoczesne, do przesytu nowoczesne. Przyszłość to być może przywrócenie równowagi między różnymi biegunami ludzkiego losu, odwrót od jednostronności i afirmacja całego, wielostronnego bogactwa ludzkiej egzystencji. No i oczywiście pojawienie się nowych dylematów i nowych wyzwań, które dziś leżą poza horyzontem naszej wyobraźni.

Anatomia rodziny jako tworu socjologicznego oznacza, że gdybyśmy badając rodzinę kolejno z punktu widzenia ekonomisty, geografa, historyka, psycho- 
loga itp., połączyli wyniki tych badań, to nie tylko nie wyczerpalibyśmy w ten sposób wszystkiego, co można powiedzieć o rodzinie ze stanowiska naukowego, lecz nie dotknęlibyśmy w ogóle samego problemu rodziny. Jest ona bowiem wielowymiarową i wieloaspektową rzeczywistością społeczną: grupą, instytucją i systemem o cechach szczególnej wspólnoty.

Społeczna misja rodziny nie wyraża się przede wszystkim w zapewnieniu trwałości gatunku, lecz w tym, że stanowi ona fundament, warunek i wzorzec społecznego ładu.

Dlatego od początku aż do tej pory inny porządek społeczny - bez rodzinnej identyfikacji i genealogii - był nie do pomyślenia, przekraczał wyobraźnię i społeczną tolerancję, nie mieścił się w oczywistym poczuciu normalności i ładu społecznego. Instytucja małżeństwa i rodziny była często ważniejsza od wyznania, przynależności etnicznej, państwowej czy narodowej. Dla usankcjonowania związku małżeńskiego oraz rodziny przynależności te często przecież zmieniano.

\section{Bibliografia}

Bryk A., Akcja afirmatywna, doktryna różnorodności a plemienna koncepcja społeczeństwa liberalnego, „Krakowskie Studia Międzynarodowe” t. 1, nr 2 (2004), s. 48n.

Kocik L., Rodzina w obliczu wartości i wzorów ponowoczesnego świata, Kraków 2006, s. 135n. Sztompka P., Szok przyszłości. Dziesięć dylematów XX wieku, „Wprost” z 5.01.2003. 
A. Uniwersytet Papieski T.5. Jana Pawła II 